\title{
HUBUNGAN ANTARA FLEKSIBILITAS DENGAN PERGELANGAN TANGAN \\ BAGIAN BELAKANG TERHADAP PEMBELAJARAN TENIS MEJA DALAM PROGRAM PENDIDIKAN JASMANI KESEHATAN MAHASISWA DAN REKREASI
}

\author{
Drs. Saripin.M.Kes AIFO, Kristy Agust,S.Pd,M.Pd, Rafni \\ sarifinunri@gmail.com
}

\section{ABSTRAK}

Berdasarkan pengamatan penulis dalam proses pembelajaran meja Belajar dimana siswa kurang baik kemampuan backhand. Ini terbukti dari backhand siswa yang belum maksimal dalam kembalinya bola, dan dalam melakukan backhand smash. Diduga jumlah faktor yang rendah seperti kondisi fisik: Fleksibilitas pergelangan tangan, kekuatan otot lengan bahu, daya tahan otot, keseimbangan, fleksibilitas punggung, kecepatan reaksi. Instrumen penelitian adalah uji kelenturan tes pergelangan tangan dan backhand, teknik pengambilan sampel porpusive penelitian ini menggunakan random sampling dengan sampel 14 siswa Prodi penjaskerek putra. Penelitian ini merupakan jenis penelitian korelasi. Kemudian, analisis data menggunakan rumus korelasi Product Moment Correlation. Berdasarkan hasil penelitian dan pengolahan data menggunakan prosedur statistik, penelitian menyimpulkan bahwa ada trade-off antara kelenturan pergelangan tangan dengan kemampuan backhand di mana rhitungnya -0058 .

Kata kunci: korelasi, Fleksibilitas pergelangan tangan, kelincahan, kemampuan backhand.

\section{ABSTRACT}

Based on observations of the author in the process tenis Learning desk where students are less good backhand ability. This is evident from the backhand students have not been up in the return of the ball, and in doing backhand smash. It is alleged the low number of factors such as the physical condition: Flexibility of the wrist, shoulder arm muscle power, muscular endurance, balance, flexibility back, the speed of the reaction. The research instrument is a test flexibility of the wrist and backhand tests, sampling technique porpusive this study using random sampling with a sample of 14 students Prodi penjaskerek son. This research is a correlation study types. Then, the data analysis using Product Moment Correlation analysis formula. Based on the results of research and data processing using statistical procedures, the study concluded that there are trade-offs between flexibility of the wrist with the ability backhand where rhitungnya -0058.

Key word: correlation, Flexibility of the wrist, agility, backhand ability. 


\section{PENDAHULUAN}

Memahami asas dan landasan pendidikan jasmani dan olahraga dalam konteks pendidikan dalam jabatan, baik sebagai guru maupun sebagai pelatih merupakan hal yang esensial. Dengan memahami asas dan landasan pendidikan jasmani dan olahraga akan dapat menempatkan diri sebagai guru yang memiliki tugas profesional untuk mengembangkan anak didik menuju manusia yang utuh. Perkembangan dan kemajuan ilmu pengetahuan dan teknologi pada masa sekarang ini sangat memberikan perubahan-perubahan di berbagai bidang ilmu pengetahuan, termasuk perubahan dalam bidang olahraga. Dengan kemajuan ilmu pengetahuan dan teknologi para pakar olahraga banyak menemukan penemuan baru, baik itu dari segi teori mengenai teknik-teknik maupun dalam bentuk peralatan yang menunjang dan berguna untuk meningkatkan prestasi dalam olahraga.

Pendidikan jasmani diharapkan dapat memberikan keterampilan gerak dan sikap positif untuk mengisi waktu dengan aktivitas yang bermanfaat bagi kehidupan anak didik, sedangkan olahraga diharapkan menjadi aktivitas yang dapat mengembangkan dan mencapai tujuan keolahragaan nasional. Menurut Undang-undang Sistem Keolahragaan Nasional (UU RI No. 3 Th. 2005) pasal 1,(2005:2-3) menjelaskan "Sistem keolahragaan nasional adalah keseluruhan aspek keolahragaan yang saling terkait secara terencana, sistematis, terpadu, dan berkelanjutan sebagai satu kesatuan yang meliputi pengaturan, pendidikan, pelatihan, pembinaan, pengembangan, dan pengawasan untuk mencapai tujuan keolahragaan nasional".

Dari penjelasan Undangundang Sistem Keolahragaan di atas bahwa pendidikan jasmani dan olahraga merupakan kesatuan yang saling terkait peningkatan, pembinaan dan pengembangan olahraga merupakan bagian untuk meningkatkan kualitas manusia yang mempunyai tujuan tertentu untuk mencapai keolahragaan nasional yang dapat mengharumkan bangsa dan negara.
Olahraga tenis meja di Indonesia merupakan bagian dari salah satu cabang olahraga permainan yang dalam proses menuju prestasi dunia,baik ditingkat Asia maupun ditingkat Internasional. Melalui olahraga ini banyak memperoleh manfaat khususnya dalam hal pertumbuhan fisik,mental dan sosial yang baik. Melalui olahraga ini juga dapat mendidik siswa untuk rajin, tekun,ulet, disiplin,dan bertanggung jawab. Belajar dengan tekun dan rajin akan memperoleh hasil yang lebih baik. Dalam belajar, ataupun pertandingan tanpa adanya disiplin dari mahasiswa tidak akan mencapai kemenangan. Menurut muhajir (2006:32) "Permainan tenis meja merupakan suatu olahraga yang dimainkan dengan menggunakan bat kayu dilapisi karet untuk memukul bola melewati jaring yang dibentangkan di atas meja".

Untuk mendapatkan pukulan backhand yang baik tentunya melalui berbagai latihan tekhnik dan fisik serta taktik. Tujuan latihan adalah meningkatkan kemampuan kondisi fisik,salah satunya kelentukan pergelangan tangan, yaitu dengan cara melakukan gerakan-gerakan pergelangan tangan secara lentuk,dan untuk mendapatkan kemampuan pukulan backhand tentu dengan cara berlatih memukul dan memainkan bola secara kontinyu.

Aktivitas olahraga yang dijalani bergantung pada kondisi fisik, seseorang yang mempunyai kondisi fisik yang baik akan mampu melaksanakan aktivitas olahraga dengan baik, sedangkan kondisi fisik yang kurang baik membuat seseorang kurang mampu melaksanakan olahraga maksimal. Kondisi fisik terdiri dari beberapa komponen yang salah satunya adalah kelenturan.

Menurut Harsono (2001:15)

"Kelentukan adalah kemampuan untuk bergerak dalam ruang sendi, kelentukan juga ditentukan oleh elastis tidaknya otot-otot dan ligamen disekitar sendi danmemiliki kelentukan akan dapat:a) mengurangi kemungkinan terjadinya cidera-cidera pada otot dan sendi, b) membantu dalam mengembangkan kecepatan kooradinasi dan 
kelincahan,

c) Membantu mengembangkan prestasi, d)Menghemat pengeluaran tenaga pada waktu melakukan gerakangerakan, e) Membantu memperbaiki sikap tubuh.

Dengan demikian orang yang lentuk adalah orang yang mempunyai ruang gerak yang luas dalam sendi-sendinya dan mempunyai otot-otot yang elastis. Menurut Nurhasan(2010:94) "Kelentukan adalah efektifitas seseorang dalam menyesuaikan diri untuk segala aktifitas dengan penguluran tubuh yang luas". Sedangkanmenurut Ismaryanti (2006:101) "Kelentukan merupakan kemampuan mengerakan tubuh atau bagian-bagiannya seluas mungkin tanpa terjadi ketegangan sendi dan cidera otot". Berdasarkan pendapat teori tersebut, kelentukan adalah kemampuan sekumpulan otot untuk melakukan gerakan secara maksimal dan rentangan yang luas.

Menyerang lawan dengan menggunakan backhand menjadi kegemaran pemain. Adanya anggapan bahwa serve yang baik akan banyak menentukan perolehan nilai. Namun demikian,dalam reli panjang maupun pendek diabad modern ini,seorang pemain dituntut utuk memusatkan perhatian pada apa yang akan dilakukan oleh lawan. Dalam permainan tenis meja banyak teknik yang dipelajari dan dimainkan,salah satu teknik tersebut adalah tehnik pukulan backhand. Dimana menurut Hodges (1996:33) "Pukulan backhand adalah pukulan yang dilakukan dengan bet yang digerakkan kearah kiri siku bagi pemain yang menggunakan tangan kanan dan kebalikanya bagi pemain yang mengunakan tangan kiri".Sedangkan menurut Sutarmin (2007:22) "Backhand adalah pukulan dari sebelah kiri".

\section{METODE PENELITIAN}

Penelitian ini dilakukan dengan menggunakan rancangan penelitian korelasional dan termasuk kedalam hubungan kausal yaitu hubungan yang bersifat sebab akibat yang bertujuan untuk mengetahui seberapa besar hubungan antara variabel bebas yaitu kelentukan pergelangan tangan dengan variabel terikat yaitu pukulan backhand. Menurut Sugiyono (2012:37), hubungan kausal adalah hubungan yang bersifat sebab akibat. Jadi disini ada variabel independen (variabel yang mempengaruhi) dan dependen (dipengaruhi). Jumlah sampel teridir dari 12 sampel putera mahasiswa dengan teknik purposive random sampling. Untuk memperoleh data dalam penelitian ini dilakukan tes pada sampel sesuai kebutuhan dengan menggunakan instrument sebagai berikut : (1) Tes kelentukan pergelangan tangan, tujuannya adalah untuk mengukur kelentukan pergelangan tangan, (2) pukulan backhand, tujuannya adalah untuk mengetahui kemampuan pukulan backhand. Setelah mendapat data dari masing-masing variabel, langkah selanjutnya adalah menguji normalitas dari masing-masing variabel untuk mengetahui kenormalan data yang diteliti. Setelah diuji kenormalannya maka data bisa dilanjutkan untuk analisi korelasi dengan korelasi product moment. Untuk korelasi product moment dengan membandingkan rhitung dengan rtabel Dengan ketentuan: (1) "apabila $r$ hitung lebih kecil dari $r$ tabel $(r h<r t)$, maka Ho diterima dan $\mathrm{Ha}$ ditolak. Tetapi sebaliknya bila $r$ hitung lebih besar dari $r$ tabel (rh>rt) maka $\mathrm{Ha}$ diterima (Sugiyono, 2012:187).

\section{HASIL DAN PEMBAHASAN}

Data yang diperoleh sebagai hasil penelitian adalah data kuantitatif melalui serangkai tes dan pengukuran terhadap 14 orang sampel yang merupakan mahasiswa pendiddikan jasmani kesehatan rekreasi. Variabelvariabel yang ada pada penelitian ini yaitu kelentukan pergelengan pergelangan tangan dilambangkan dengan $\left(\mathrm{X}_{1}\right)$, pukulan backhand dengan $Y$ sebagai variabel terikat. Deskripsi data dari masing-masing variabel ini dapat dikemukakan sebagai berikut:

\section{Data Hasil dari Tes}

Kelentukan pergelangan tangan

Setelah dilakukan tes kelentukan pergelangan tangan, melalui tes kelentukan pergelangan tangan. Berdasarkan hasil analisis adalah sebagai berikut : skor tertinggi $78^{\circ}$, skor terendah $55^{\circ}$, dengan mean 68.14 , standar diviasi 8.02 berikut dijelaskan tentang distribusi frekuensi data Power Otot Tungkai. 
Tabel 4.1 Distribusi frekuensi Kelentukan Pergelangan Tangan $(\mathrm{X})$

\begin{tabular}{|l|c|c|}
\hline $\begin{array}{c}\text { Kelas } \\
\text { Interval }\end{array}$ & $\begin{array}{c}\text { Frequency } \\
\text { Absolute }\end{array}$ & $\begin{array}{c}\text { Frequency } \\
\text { Relative }\end{array}$ \\
\hline $55-59$ & 2 & $14.29 \%$ \\
\hline $60-64$ & 3 & $21.43 \%$ \\
\hline $65-69$ & 3 & $21.43 \%$ \\
\hline $70-74$ & 1 & $7.14 \%$ \\
\hline $75-79$ & 5 & $35.71 \%$ \\
\hline $\begin{array}{l}\text { Jumlah } \\
\text { Sampel }\end{array}$ & 14 & $100,00 \%$ \\
\hline
\end{tabular}

Berdasarkan hasil distribusi frekuensi di atas dari 14 sampel, ternyata 2 orang sampel $=14.29 \%$ mendapat nilai tes kelentukan pergelangan tangan dengan rentangan nilai 55-59, kemudian 3 orang sampel $=21.43 \%$ mendapat nilai tes kelentukan pergelangan tangan dengan rentangan 60-64, kemudian 3 orang sampel $=21.43 \%$ mendapat nilai tes kelentukan pergelangan tangan dengan rentangan 65-69, kemudian 1 orang sampel $=7.14 \%$ mendapat nilai tes kelentukan pergelangan tangan dengan rentangan 70-74, kemudian 5 orang sampel $=35.71 \%$ mendapat nilai tes kelentukan pergelangan tangan dengan rentangan 75-79. Untuk lebih jelasnya berikut histogram data hasil tes kelentukan pergelangan tangan.

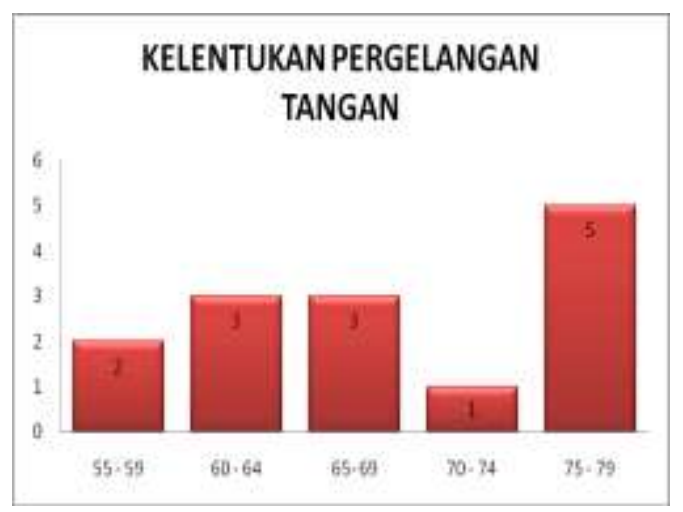

\section{Gambar 4.1. Histogram Data Hasil Kelentukan Pergelangan Tangan}

\section{Data Hasil dari Pukulan Backhand}

Setelah dilakukan tes pukulan backhand. Berdasarkan hasil analisis backhand test adalah sebagai berikut : skor tertinggi 59, skor terendah 31 , dengan mean 42.79, standar diviasi 10.56, berikut dijelaskan tentang distribusi frekuensi data pukulan backhand.

\begin{tabular}{|l|c|r|}
\hline $\begin{array}{c}\text { Kelas } \\
\text { Interval }\end{array}$ & $\begin{array}{c}\text { Frequency } \\
\text { Absolute }\end{array}$ & $\begin{array}{c}\text { Frequency } \\
\text { Relative }\end{array}$ \\
\hline $31-36$ & 6 & $42.86 \%$ \\
\hline $37-42$ & 2 & $14.29 \%$ \\
\hline $43-48$ & 2 & $14.29 \%$ \\
\hline $49-54$ & 0 & $0.00 \%$ \\
\hline $55-60$ & 4 & $28.57 \%$ \\
\hline $\begin{array}{l}\text { Jumlah } \\
\text { Sampel }\end{array}$ & 14 & $100,00 \%$ \\
\hline
\end{tabular}

Tabel 4.1 Distribusi frekuensi data Pukulan Backhand

Berdasarkan hasil distribusi frekuensi di atas dari 14 sampel, ternyata 6 orang sampel $=42.86 \%$ mendapat nilai tes Pukulan Backhand dengan rentangan nilai 31-36, kemudian 2 orang sampel $=14.29 \%$ mendapat nilai tes Pukulan Backhand dengan rentangan 37-42, kemudian 2 orang sampel $=14.29 \%$ mendapat nilai tes Pukulan Backhand dengan rentangan 43-48, kemudian 4 orang sampel $=28.57 \%$ mendapat nilai tes pukulan backhand dengan rentangan 55 - 60. Untuk lebih jelasnya berikut histogram data hasil tes Koordinasi Mata dan Kaki.

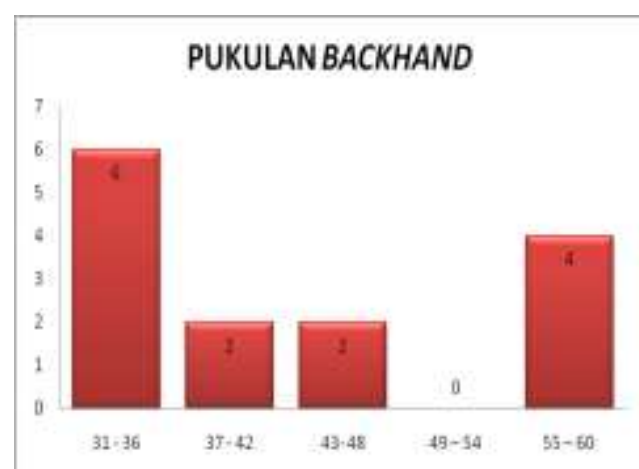

Gambar 4.1. Histogram Data Hasil Pukulan Backhand

\section{Pengujian Persyaratan Analisis}

Setelah data diperoleh dari hasil kelentukan pergelangan tangan (X), dan pukulan backhand (Y) maka data akan dianalisis dengan uji normalitas data dengan uji Lilifors. Nilai Lilifors observasi maksimum dilambangkan $L_{\text {hitung dimana nilai }}$ $\mathrm{L}_{\text {hitung }}<\mathrm{L}_{\text {tabel }}$ maka sampel berasal dari populasi berdistribusi normal (Ritonga,2007 : 63). Hasil uji normalitas terhadap penelitian dapat dilihat pada tabel sebagai 4.3 berikut. 
Tabel 1 Hasil Uji Normalitas.

\begin{tabular}{|c|c|c|c|}
\hline Variabel & $\mathrm{L}_{\text {hitung }}$ & $\mathrm{L}_{\text {tabel }}$ & Keterangan \\
\hline $\mathrm{X}$ & 0.1093 & 0,227 & $\begin{array}{c}\text { Berdistribusi } \\
\text { Normal }\end{array}$ \\
\hline $\mathrm{Y}$ & 0.1989 & 0,227 & $\begin{array}{c}\text { Berdistribusi } \\
\text { Normal }\end{array}$ \\
\hline
\end{tabular}

Dari tabel diatas terlihat bahwa $\mathrm{L}_{\text {hitung }}$ variabel $\mathrm{X}=0.1093, \mathrm{~L}_{\text {hitung }}$ dan $\mathrm{L}_{\text {hitung variabel } \mathrm{Y}=0.1989 \text { dimana }}$ $\mathrm{L}_{\text {tabel }}$ diperoleh $0,227(\alpha=0,05)$, dengan demikian $\mathrm{L}_{\text {hitung }}=0.1093<$ $\mathrm{L}_{\text {tabel }} 0,227$ pada variabel $\mathrm{X}, \mathrm{L}_{\text {hitung }}=$ $0.1989<\mathrm{L}_{\text {tabel }}=0.227$ pada variabel $\mathrm{Y}$ , dengan kata lain disimpulkan bahwa data $\mathbf{X}$ dan $\mathbf{Y}$ berdistribusi normal.

\section{Pengujian Hipotesis}

Untuk menguji hipotesis satu berdasarkan perhitungan dengan korelasi produc moment. Berdasarkan analisis yang dilakukan, maka didapat skor rata-rata kelentukan pergelangan tangan sebesar 68.14 dengan simpangan baku 8.02. Untuk skor ratarata hasil pukulan backhand didapat 42.79 dan simpangan baku 10.56 dan dari perhitungan korelasi "r" pada product moment ( $r x y$ ) diperoleh $\mathrm{r}_{\text {hitung }}=$ -0.058. Artinya terdapat hubungan yang tidak searah antara kelentukan pergelangan tangan dengan kemampuan pukulan backhand dalam permainan tenis meja.

\section{KESIMPULAN DAN SARAN Kesimpulan}

Berdasarkan hasil penelitian dan pengolahan data dengan memakai prosedur statistik penelitian maka disimpulkan bahwa terdapat hubungan yang tidak searah antara kelentukan pergelangan tangan dengan kemampuan pukulan backhand di mana rhitungnya -0.058 .

\section{Rekomendasi}

Berdasarkan hasil penelitian kesimpulan dalam penelitian ini, dapat dikemukakan saran-saran sebagai berikut:

1. Dosen, dalam upaya meningkatkan kemampuan pukulan backhand secara efektif hendaknya segala aspek kondisi fisik diperhatikan

2. Bagi mahasiswa yang mempelajari olahraga tenis meja yang ingin meningkatkan keterampilan pukulan backhand hendaknya melakukan metode latihan yang dapat meningkatkan pukulan backhand.

3. Peneliti yang hendak meneliti permasalahan ini lebih lanjut, agar kiranya dapat mempertimbangkan berbagai keterbatasanketerbatasan dalam penelitian ini.

\section{DAFTAR PUSTAKA}

Arikunto. (2010). Prosedur Peneltiian Suatu Pendekatan Praktik. Jakarta: Rineka cipta. Cet. Ke-14.

Hodges, Larry. (1996). Tenis Meja Tingkat Pemula. Jakarta: Raja Grafindo

Harsono. (2001) Latihan Kondisi Fisik. Jurusan Ilmu Keolahragaaan Fakultas

Ilmu Pendidikan Universitas Negeri Malang.

Ismaryati. (2008). Tes dan Pengukuran

Olahraga. Surakarta: Lembaga Pengembangan Pendidikan (LPP) dan UPT UNS Press.

Mokholid, Agus. (2006). Pendidikan Jasmani, Olahraga dan Kesehatan. Jakarta: Yudistira.

Muhajir. (2006). Pendidikan Jasmani. Jakarta: Yudistira

Nurhasan. (2011). Tes dan Pengukuran Olahraga. Fakultas Keguruan dan Ilmu Pendidikan Universitas Islam Indragiri.

Riduwan. (2004). Belajar Mudah Penelitian untuk Guru, Karyawan dan Peneliti Pemula. Bandung: Alfabeta.

Salim, Agus. (2007). Buku Pintar Tenis Meja. Jember.

Sujana. (2005). Metode Statistika. Bandung: Tarsito.

Sutarmin. (2007). Terampil Berolahraga Tenis Meja. Surakarta: Intermedia

Undang-Undang Republik Indonesia Nomor. 3 Tentang Sistem Keolahragaan Nasional.(2005). Kantor Kementrian Negara Pemuda dan Olahraga Republik Indonesia. 